\title{
Does Working Capital Management Matter in Dividend Policy Decision? Empirical Evidence from Nigeria
}

\author{
Adesina Olugoke Oladipupo ${ }^{1} \&$ Peter Okoeguale Ibadin \\ ${ }^{1}$ Department of Accounting, Faculty of Management Sciences, University of Benin, Benin City, Nigeria \\ Correspondence: Adesina Olugoke Oladipupo, Department of Accounting, Faculty of Management Sciences, \\ University of Benin, Benin City, Nigeria. Tel: 234-80-5516-0668. E-mail: sinaoladipupo@yahoo.com
}

Received: August 14, 2013

Accepted: September 16, 2013

Online Published: October 8, 2013

doi:10.5430/ijfr.v4n4p140

URL: http://dx.doi.org/10.5430/ijfr.v4n4p140

\begin{abstract}
This study examines the relationship between dividend payout ratio and working capital management and the effect of firm's working capital management practice on its dividend payout ratio. The working capital management is measured by the net trade cycle, current ratio and debt ratio. The data used in this study were obtained from twelve manufacturing companies quoted on the Nigeria Stock Exchange between 2002 and 2006. The data wer analysed using the Pearson product moment correlation technique and ordinary least square (OLS) regression technique. The results show that dividend payout ratio was influenced positively by profitability and net trade cycle but negatively by growth rate in earnings. Corporate profitability, working management, and growth in earnings have statistically insignificant effects on the dividend payout ratio at 5\% confidence level. Hence, we can conclude that from this study working capital management is not significant in dividend policy decision. However, the result cannot be generalized owing to the problem of small sample size, seemingly poor model specification and failure to adopt the robust modern statistical technique provided by the fixed and random effects of panel data regression technique.
\end{abstract}

Keywords: working capital management, corporate profitability, dividend payout ratio and growth in earnings

\section{Introduction}

Increasing shareholders' wealth either in form of dividend and/or capital gains is usually one of the things desired by any firm. Dividend refers to the return that accrues to shareholders as a result of the money invested in acquiring stock of a given company. In maximizing shareholders' wealth, it becomes necessary therefore that both investment decisions and dividend decisions should be given serious attentions simultaneously. Investment decisions would involve the company deciding which project to accept and which one not to accept. Investment decisions would include decisions to raise funds to execute the projects accepted. On the other hand, dividend decisions focus on how a company determines what portion of its profits to retain and what proportion to pay out as dividend.

Ross, Westerfeild and Jordan (1996) opined that the objective of dividend policy is to maximize shareholders' return, which includes dividend and capital gains. For this reason, most firms are interested in how much of their earnings or profits they should pay out to shareholders and how much they should retain for further investment. Retention of earnings is encouraged for firm's investment purposes without the involvement of shareholders. This would help the firms to avoid or minimise costs associated with borrowing and also avoid the dilution of control. However, it is important that the interest of the shareholders be considered because some are solely dependent on their returns (i.e. dividends). It is for this reason that Osaze and Anao (1990) observed that the role of a financial manager is to strike a balance between payout and retention of earnings.

Dividend comes in several forms: cash dividend and capital appreciation. Cash dividend payment reduces corporate cash and retained earnings. Due to this fact many organisations sometimes decide to employ other forms of dividend that include stock dividends, stock split, and share repurchases apart from cash dividend (Pandey, 2004; Akinfure, 2006). While these alternatives can be considered, it is important to know that there may be investors such as retired individuals who would prefer current income to growth in stock value (Smith, 2008). This is true for some investors, especially when the dividend receivable from their investments is the sole means of survival or in a situation where the individual investors have better investment opportunities than that of the organisations.

However, dividend payment is only possible if there is profit and that the profit is backed up by cash. There is 
therefore the need to balance profitability with liquidity through effective working capital management. This is in accordance with the legal provisions of sections 379-382 of Companies and other Allied Matters Act (CAMA, 2004) in Nigeria. Working capital, which is the difference between current assets and current liabilities, is a connecting rod that affects the liquidity and profitability of any firm. However, there is a trade-off between liquidity and profitability of a firm. A firm needs profitability to achieve growth and success. A firm also requires some measure of liquidity to avert insolvency and liquidation problem. To meet up with dividend demand of shareholders firms must be liquid. And to achieve growth and maintain survival firms need to experience profitability as well. How could a firm be able to achieve these varying and conflicting objectives? Can a firm find panacea in managing working capital? Can effective management of working capital bring about high profitability and dividends payout ratio?

This study examines the tripartite relationships among working capital management, corporate profitability and dividend payout ratio. The aim is to examine the nexus between working capital management vis-a-vis corporate profitability and dividend payout. The objectives of the study are to determine the relationships between the working capital management and dividend payout and the effect of working capital management on dividend payout. The research hypotheses tested are that there is no significant relationship between working capital management and dividend payout ratio; and that working capital management and corporate profitability do not significantly affect dividend payout ratio.

\section{Materials Studied}

Right from the seminal work of Lintner (1956) numerious studies have attempted to identify the factors influencing dividend decision in organizations. Many factors have been considered as influencing dividend decisions such as profitability, cash flow, lagged dividend, debt -equity ratio, sales growth, liquidity, share price behaviour, capital expenditure, retained earnings, beta (systematic risk), price-earnings ratio, investment opportunities, promoter holding, firm size, earnings volatility and interst coverage ratio. The search continues up till today. To the best of our knowledge no study has considered the effect of working capital management on the firm's payout ratio. Here we present a review of some existing studies on the determinants of dividend decisions in organizations. Adaoglu (2000) examined empirically whether the Istanbul Stock Exchnage (ISE) firms followed stable cash dividend policies in a regulatory environment that imposed manadatory dividend policies. The results showed that ISE firms followed unstable cash dividend policies and the earnings of a firm in a particular year were a major factor that determined the amount of cash dividend. Omet (2004) examined the dividend policy behaviour of companies listed on the Jordanian capital market. Using a panel data for a period 1985-1999, the study showed that Jordanian companies followed stable cash dividend policicies. The imposition of $10 \%$ tax rate on dividends in 1996 did not lead to any significant changes in the dividend policies. Musa (2009) used the parsimonious multiple regression model to examine the dividend policy of 53 firms quoted on the Nigerian Stock Exchange (NSE) during the period 1993 to 2002. Looking at the effects of eight variables on the dividend policy of the quoted firms in Nigeria, the results showed that current earnings, previous dividend and cash flow were significant while other factors such as investment, net current assets, growth, firm size and industry classification were found insignificant in dividend decision. Adesola and Okwong (2009) used data for the period between 1996 and 2006 from 27 companies quoted in Nigerian Stock Exchange to examine the dividend behaviour of Nigerian firms. The results showed that an average earnings per share (or average earnings) were still the most significant determinant of average dividend payment. They also confirmed that current dividend payment and earnings per share were significant in explaining the observed differential share market prices of quoted firms in Nigeria. However, recent data showed that the magnitude of the impact of earnings or earning per share was now greater than that of current dividend payment, which used to be the most significant as reported in previous studies such as Nyong (1990) and Adesola (2004). Furthermore, they also confirmed that growth prospect and firm size had no significant impacts on the dividend behavior of corporate firms, which was inconsistent with the findings of Adelegan (2001).

Gill, Biger, and Tibrewala (2010) examined the determinants of dividend payout ratios in the American service and manufacturing firms. They found that for the entire sample the dividend payout ratio was the function of profit margin, sales growth, debt-to-equity ratio, and tax. For firms in the Services industry the dividend payout ratio was the function of profit margin, sales growth, and debt-to-equity ratio. For manufacturing firms they found that dividend payout ratio was the function of profit margin, tax, and market-to-book ratio. They also found that the results were different when the dividend payout ratio was defined as the ratio between the cash dividend and the after-tax cash flow, not the after tax earnings of the companies. Imran (2011) used data of 36 firms listed on Karachi Stock Exchange for the period between 1996 and 2008 to determine the factors influencing the dividend payout decisions in Pakistan's engineering sector. Using the fixed and random effects of panel data regression technique the results showed the previous dividend per share, earnings per share, profitability, cash flow, sales growth, and firm size were the most significant 
factors affecting the dividend policy in Pakistan engineering sector. Kinfe (2011) studied the factors determing dividend payout policy in Ethiopia banking industry. Using a panel dataset from banks between 2006 and 2010, the results showed that dividend payments were related strongly and directly to firm size and lagged dividend per share, but negatively related to the liquidity ratio. No relationships were observed between dividend payout and profitability, leverage, and growth respectively. Mehta (2012) also studied the factors the UAE companies considered in making dividend decisions. Using data for five years (2005-2009) from the firms listed on the Abu Dhabi Stock Exchange, the study revealed that profitability and firm size were the most significant factors in the dividend decisions by UAE Firms while risk, liquidity, and leverage were insignificant in dividend decision making. Uwuigbe, Jafaru and Ajayi (2012) examined the relationship between the financial performance and dividend payout and between ownership structure, firm size and dividend payouts among listed companies in Nigeria. Using data obtained from 50 firms over the period 2006-2010, they observed positive correlation between the firm performance and dividend payout while ownership structure and firm size had significant impact on the dividend payout of firms under study. Aizomaia and Al-Khadhiri (2013) considered the factors affecting dividend decisions by companies quoted on the Saudi Arabia Stock Exchanges. Using a panel data for the period 2004 - 2010 for 105 non-financial firms listed in the stock market, they examined the effects of earnings per share, previous dividends represented by dividends per share for last year, growth, debt to equity ratio, beta and capital size on dividend per share. The results showed that Saudi listed non-financial firms relied on current earnings per share and past dividend per share in their dividend payment decisions. Chauhan and Bhayani (2013) assessed the dividend payout policies of Indian companies. Using data collected from BSE Sensex -30 companies dividend payout was regressed on profitability, liquidity and size of business. The results of the study showed that dividend policies of Indians companies were highly influenced by profitability and liquidity of the firms. From the foregoing, we observed that studies on determinants of dividend payout have considered many factors but no one to the best of our knowledge has considered the effect of working capital management on the firm's payout ratio. This is gap that this study intends to fill.

\section{Methods}

\subsection{Theoretical Framework and Model Specification}

Two models of dividend payout decision were considered in this study, namely; Rozeff model (1982) and that of Hexter, Holder and Langrel Model (1998). Rozeff model (1982) considered the past growth $\left(\mathrm{G}_{\mathrm{p}}\right)$; expected future growth $\left(\mathrm{G}_{\mathrm{f}}\right)$ and agency cost $(\mathrm{AC})$ as the determinants of dividend payout ratio (DPP). This is mathematically expressed as follows:

$$
\mathrm{DPR}=\beta_{0}+\beta_{1} \mathrm{G}_{\mathrm{p}}+\beta_{2} \mathrm{G}_{\mathrm{f}}+\beta_{3} \mathrm{AC}
$$

where,

$\mathrm{DPR}=$ Dividend payout ratio

$\mathrm{G}_{\mathrm{p}=}$ the past growth rate of dividend payout

$\mathrm{G}_{\mathrm{f}}=$ the expected growth rate of dividend payout

$\mathrm{AC}=$ Agency Cost

The second model is that of Hexter, Holder and Langrel in 1998. This model expresses dividend payout ratio (a dependent variable) as a function of the firm size, number of lines of business of a firm, agency cost and the degree of free cash flow available. This is expressed as follows.

$$
\mathrm{DPR}=\beta_{0}+\beta_{1} \mathrm{FS}+\beta_{2} \mathrm{NBL}+\beta_{3} \mathrm{AC}+\beta_{3} \mathrm{FCSA}
$$

where,

$\mathrm{DPR}=$ Dividend payout ratio

$\mathrm{FS}=$ Firm size,

$\mathrm{NBL}=$ Number of Business Lines of a firm,

$\mathrm{AC}=$ Agency cost, and

$\mathrm{FCSA}=$ Free cash flow available.

\subsection{Model for the Present Study: Dividend Payout Ratio -Working Management Model}

To the best of our knowledge no existing study models the effect of working capital management on the firm's dividend payout policy. In this study we model dividend payout as a function of working capital management. We control for the effect of corporate profitability and growth of earnings. Thus, we regressed dividend payout ratio of a 
firm on its working capital management represented by net trade cycle (NTC), profitability and growth rate of earnings (Oladipupo \& Okafor, in press). This is mathematically expressed as follows:

$$
D_{p}=\beta_{0}+\beta_{1} P_{t}+\beta_{2} \text { NTC }+\beta_{3} \text { GR }
$$

where,

$D_{p}=$ Dividend Payout Ratio, estimated as ratio of dividend per share and earnings per share.

$\mathrm{P}_{\mathrm{t}}=$ Profitability, estimated as Operating Income + Deprecation

Total Assets

NTC $=$ Net Trade Cycle (in number of days), estimated as (Inventory + Account Receivable - Account Payable) $\mathrm{x}$ $365 /$ Sales

$\mathrm{GR}=$ Growth rate of earnings, estimated as $(1-\mathrm{Dp}) \times \underline{\text { Profit after tax }}$

Net-worth (Equity)

The a-priori signs of $\mathrm{B}_{0}, \mathrm{~B}_{1}, \mathrm{~B}_{2}, \mathrm{~B}_{3}>0$

\subsection{Methods of Data Collection and Data Analysis}

The data for this study were collected from the audited annual accounts and reports of 12 manufacturing companies listed on the Nigerian Stock Exchange between 2002 and 2006 to have 60 pooled dataset. Data obtained from corporate annual reports included account receivables, account payable, inventory, operating income, net worth, current assets, current liabilities, sales, total debt, depreciation, dividend per share, total assets, earnings per share, and profit after tax. Data collected were analysed using Pearson Product Moment Correlation technique and Ordinary Least Square Regression technique provided by the SPSS version 16. We tested the first hypothesis by using Pearson product moment correlation analysis and the second hypothesis by ordinary least square regression analysis.

\section{Results}

We present the results of the ordinary least square (OLS) regression analysis conducted in this study in Table 1 . The model regresses the dividend payout ratio (the dependent variable) on the corporate profitability $\left(\mathrm{P}_{\mathrm{t}}\right.$ ), net trade cycle (NTC) as measure of working capital management and growth rate in earnings (GR), which are independent variables.

Table 1. Coefficients for dividend payout ratio model

\begin{tabular}{llll}
\hline \multicolumn{4}{l}{ Dividend Payout Ratio } \\
\hline Regressors & \multicolumn{4}{l}{ Unstandardised Coefficients } \\
\hline & Beta & Std Error & T-Ratio \\
\hline Constant & 0.066 & 0.451 & 1.147 \\
\hline Profitability (Pt) & 2.189 & 1.902 & 1.151 \\
\hline Net trade cycle & 0.002 & 0.002 & -0.771 \\
\hline Growth rate of earnings (GR) & -0.010 & 0.013 & 0.771 \\
\hline
\end{tabular}

Source: Authors (2013)

Adjusted $\mathrm{R}^{2}=0.03$ and $\mathrm{F}=0.58, \mathrm{~F}$ table value, d.f $(3,58)=3.15$, Durbin Watson statistic $=2.06$.

The regression equation is presented below.

$$
\mathrm{D}_{\mathrm{p}}=0.07+2.19 \mathrm{P}_{\mathrm{t}}+0.002 \mathrm{NTC}-0.01 \mathrm{GR}
$$

Going by the value of adjusted $\mathrm{R}^{2}$ of 0.03 , it shows that only $3 \%$ of the total systematic variations in dividend payout ratio can be explained by the variations in profitability, net trade cycle (working capital management) and growth rate in earnings. This shows that about $97 \%$ of the systematic variations in dividend payout can be accounted for by others factors outside the model. This is a show of poor model specification. Again, the value of F-statistic of 0.58 is very low compared to the critical value of F-statistic, which also suggests that the model suffers the test of goodness of fit.

However, all the regressors except growth rate in earnings (GR) passed their a-priori signs. Dividend payout ratio is positively related to corporate profitability $\left(\mathrm{P}_{\mathrm{t}}\right)$ and net trade cycle $(\mathrm{NTC})$ but negatively related to the growth rate in 
earnings (GR). The positive relationship observed between dividend payout and profitability is consistent with the results of Mehta (2012) and Chauhan and Bhayani (2013) while the negative relationship between dividend payout and the growth rate in earnings is consistent with the result of Saxena (1999). The positive relationship between the dividend payout and net trade cycle (NTC), which is a measure of working capital is novel to this study and no prior study to compare with. In terms of the elasticity of dividend payout to the individual independent variables, we observe that a unit rise in profitability will lead to 2.19 units increase in dividend payout ratio. Also a unit rise in net trade cycle (NTC) will lead to 0.002 unit increase in dividend payout ratio $\left(\mathrm{D}_{\mathrm{p}}\right)$. A unit increase in growth rate in earnings (GR) will lead to a 0.01 unit fall in dividend payout ratio. This shows that the firms under study are growth seeking firm, which would prefer to plough back earnings rather than increasing dividend payment. In terms of the relative significance of each of the independent variables in explaining the variations in the dividend payout, we observe that the t-values of all the independent variables are quite low as they are less than \pm 2.0 . This shows that none of the independent variables is significant in explaining the systematic variations in dividend payment. The result that profitability has insignificant impact on dividend payout is consistent with the result of Kinfe (2011) but inconsistent with the result of Chauhan and Bhayani (2013). The insignificant impact of growth rate in earnings on the dividend payout is inconsistent with the result of Adesola and Okwong (2009). The insignificant impact of working capital management on dividend payment is novel here and no prior study to compare with.

\section{Discussion}

From the analysis above we observed positive relationships between the dividend payment and profitability and working capital management and negative relationship between the dividend payment and growth in earnings among firms under study. However, dividend payout ratio is not greatly influenced by profitability, working capital management (represented by net trade cycle) and growth in earnings. The positive relationship between the net trade cycle (NTC) and the dividend payout ratio shows that the higher the working capital management the higher the dividend payout ratio. A shorter trade cycle should mean a reduction in liquidity but an increase in profitability and dividend payout because dividends are expected to be paid only out of distributable profits. Payment of dividends also would mean less retained earnings to finance future trade.

The insignificant impact of working capital (represented by net trade cycle) on dividend payout shows that from this study it would appear that working capital management may not matter in dividend payment decision. In fact, the insignicance of profitability, net trade cycle (a measure of working capital management) and growth in earnings on dividend payout show that the factors the firms consider in dividend policy decisions are quite outside the three variables of interest in this study. This may call for further study on this issue.

\section{Conclusion}

We can conclude evidentially from this study that working capital management is not a critical factor in the matter of dividend policy by the firms under study. Can we generalize the results of this study by saying that working capital management does not matter in dividend policy decisions amongst public firms in Nigeria? Obviously, no because this study is an exploratory one and is fraught with some limitations. Some of these limitations include the smallness of the sample size. Again, the sampled firms are homogeneous as they are all from manufacturing subsector of the Nigerian economy. Furthermore, the methodology adopted is simplistic as we used pooled ordinary least regression technique. There is also the possibility of poor model specification as the model failed the test of goodness of fit going by the low values of F-statistic and adjusted $\mathrm{R}^{2}$. For future study, we hereby recommend that the model should include as many other firm specific caharacteristics as evident by the literature to be the factors influencing dividend payout. The omission of the past dividend payout of the model violates the fundamental assumption that most firms are influenced by their history of dividend payment while making current dividend decisions. The sample size should also increase spatially and temporally, i.e. include more companies from various subsectors and take data over longer period. Methodologically, advantage of panel data regression analysis using fixed and random effects should be explored to know whether there is heterogeneity in the observations across the firms and time.

\section{Acknowledgements}

We thank the independent reviewers of this manuscript for job well done.

\section{References}

Adaoglu, C. (2000). Instability in the dividend policy of the Istanbul Stock Exchange (ISE) corporations: Evidence from an emerging market. Emerging Market Review, 1, 252-270.

Adelegan, O. (2001). The impact of growth prospect, leverage and firm size on dividend behaviour of corporate firms in Nigeria. Manuscript, Department of Economics, University of Ibadan. 
Adesola, W. A., \& Okwong, A.E. (2004). An empirical study of dividend policy of quoted firms in Nigeria. Global Journal of Social Sciences, 8(1), 85-101.

Adesola, W. A. (2004). An empirical study of dividend policy of quoted firms in Nigeria. An unpublished M.Sc Thesis, University of Calabar.

Aizomaia, T. S. F., \& Al-Khadhiri, A. (2013). Determination of Dividend Policy: The Evidence from Saudi Arabi. International Journal of Business and Social Sciences, 4(1), 181-192

Akinfure, O. (2006). Financial management. Lagos: Ceemel Publishers, pp.371-551.

Chauhan, P., \& Bhayani, S. J. (2013). An empirical analysis of dividend payout policy in Indian corporate. Retrieved from http://www.scribd.com/doc/16742896/Dividend-Payout-Policy-Professor-Pratapsinh-Chauhan

Companies and Other Allied Matters Act [CAMA]. (2004). Cap.20, Law of Federation of Nigeria. Lagos.

Gill, A., Biger, N., \& Tibrewala, R. (2010). Determinants of Dividend Payout Ratios: Evidence from United States. The Open Business Journal, 3, 8-14, 1874-9151/10 2010 Bentham.

Hamill, P. A. (2012, August). What determines the dividends payout ratio for Jordanian industrial firms? Journal of Emerging Market Finance, 11(2), 161-188.

Imran, K. (2011). Determinants of dividend payout policy: A case of Pakistan Engineering Sector. The Romanian Economic Journal, 41, 47-60.

Kinfe, T. (2011). Determinants of dividend payout: An empirical study on bank industry in Ethiopia. Unpublished M.Sc. Accounting thesis, Department of Accounting and Finance, 106pp.

Lintner, J. (1956). Distribution of income and dividends among Corporations, retained earnings and taxes. American Economic Review, 46(2), 97-113.

Manos, R. (2001). Capital structure and dividend policy: Evidence from emerging markets. Unpublished Ph.D thesis, Department of Accounting and Finance, University of Birmingham, 502pp.

Mehta, A. (2012, March). An empirical analysis of determinats of dividend policy- Evidence from the UAE companies. Global Review of Accounting and Finance, 3(1), 18-31.

Musa, I.F. (2009). The dividend policy of firms quoted on the Nigerian stock exchange: An empirical analysis. African Journal of Business Management, 3(10), 555-566.

Nyong, M. O. (1990). Dividend policy of quoted companies: A behavioural approach using recent data. Manuscript. Department of Economics, Lagos State University.

Oladipupo, A.O., \& Okafor, C.A. (in press). Relative contribution of working capital management to corporate profitability and dividend payout ratio: Evidence from Nigeria.

Omet, G. (2004). Dividend policy behaviour in the Jordanian capital market. International Journal of Business, 9(3), 287-300

Osazee, B.F., \& Anao, A.R. (1989). Managerial Finance. Benin-City: University of Benin Press, pp.85-98.

Pandey, I.M. (2001). Financial Management. New Delhi: Vikas Publishing House, PVT Ltd, pp.577-640.

Ross, S.A., Westerfeild, R.W., \& Jordan, B.D. (1996). Essentials of Corporate Finance. Boston: Irwin McGraw-Hill, pp.381-462.

Smith, R.H. (2008). Financial Management- Dividend Policy. Retrieved from http://www.google.com

Uwuigbe, U., Jafaru, J., \& Ajayi, A. (2012). Dividend policy and firm performance: A study of listed firms in Nigeria. Accounting and Management Information Systems, 11(3), 445-454. 